\title{
A educação jesuítica na Amazônia Setecentista e os confrontos com o Pombalismo
}

\section{Resumo}

A atividade educativa desenvolvida pelos jesuítas no Estado do GrãoPará, embora profícua, nem sempre foi pacífica. Se havia objetivos divergentes, desafios e ameaças existentes nas relações entre índios e Jesuítas, entre esses últimos e os representantes de Pombal, a situação era mais crítica. Na verdade, os dirigentes da política pombalina consideravam e temiam seriamente os Jesuítas como "inimigo" a ser enfrentado. E nisso, eles tinham os colonos europeus como aliados preferenciais. Eles percebiam nos padres missionários jesuítas uma espécie de ameaça, pois, fortemente organizados nas aldeias, os padres monopolizavam a mão de obra indígena. Neste contexto, Antonio Vieira representava uma espécie de efígie na defesa da liberdade dos nativos.

Palavras-chave: Educação. Grão-Pará. Jesuítas. Pombal.

\author{
Alberto Damasceno \\ Universidade Federal do Pará - \\ UFPA - Belém/PA - Brasil \\ albertod@ufpa.br

\section{Emina Santos} \\ Universidade Federal do Pará - \\ UFPA - Belém/PA - Brasil \\ emina@ufpa.br

\section{Daniel Palheta} \\ Universidade Federal do Pará - \\ UFPA - Belém/PA - Brasil \\ danielrodrigues2001@yahoo.co \\ m.br
}

\section{Para citar este artigo:}

DAMASCENO, Alberto; SANTOS, Emina; PALHETA, Daniel. A educação jesuítica na Amazônia Setecentista e os confrontos com o Pombalismo. Revista Linhas. Florianópolis, v. 19, n. 41, p. 259-291, set./dez. 2018. 


\title{
The jesuitic education in the Setecentist Amazon and the confronts with Pombalism
}

\begin{abstract}
The educational activity developed by the Jesuits in State of Grão-Pará, though profitable, wasn't always peaceful. If there were divergent goals, challenges and threats in relationship between Indians and Jesuits, the latter's contact with representatives of Pombal was most critical. In fact, the leaders of Pombal policy considered and feared seriously the Jesuits as "enemy" to be faced. In this case, they had European settlers as preferential allies. They perceived the Jesuit missionary priests as a sort of threat, strongly organized in the villages, monopolizing the indigenous labor work. In this context, Antonio Vieira represented a kind of effigy in defense of natives' freedom.
\end{abstract}

Keywords: Education. Grão-Pará. Jesuits. Pombal. 


\section{A relação entre jesuítas e a Coroa Portuguesa no Grão-Pará}

Os religiosos foram os responsáveis pelas primeiras experiências pedagógicas na colônia devido à necessidade de cristianizar os nativos. Nesse ínterim, a Companhia de Jesus chegou, em 1658, no Estado do Grão-Pará, passando a deter forte influência na organização cultural por meio da ação educativa, e apresentando duas principais finalidades para o trabalho das ordens religiosas nos territórios em processo de conquista: "espiritual, perseguindo a conversão do nativo à religião cristã, e política, operacionalizando-se através dos aldeamentos, pois o fato dos nativos serem nômades dificultava o trabalho da catequização" (DAMASCENO, 2012, p. 82).

Problematizamos, desta feita, a ação jesuítica como um ostensivo aparelho estatal de aculturação, ou seja, de um mecanismo organizado de modificação cultural dos indivíduos, com vistas a inseri-los em um processo civilizatório cujas premissas religiosas se verificam como um importante aparato de controle da moral.

Sobre a expulsão da Ordem Jesuítica, corroboramos com Gomes quando emerge algumas propostas para o fenômeno pelo qual o Estado Português passava na época:

Quanto à secularização das estruturas do Estado, pergunto-me: não seria esse um dos motivos que levaram à expulsão dos jesuítas? E interrogome novamente: a expulsão dos jesuítas foi uma causa ou foi um efeito? Quero dizer: o Marquês de Pombal - e o mesmo aconteceu com quase todos os governantes, por essa Europa fora... - criou um sistema estatal de ensino porque, expulsos os jesuítas, o país se viu perante um vazio nesse domínio, ou expulsou os jesuítas porque sentiu ou pressentiu (embora esse sentimento ou pressentimento não fosse bem explicitado, mesmo no seu próprio espírito) que era atribuição do Estado criar um sistema público de ensino? (GOMES, 1995, p. 36-7)

Desta forma, podemos dividir a educação colonial na Amazônia de acordo com o que propõe Avelar:

A educação no Brasil colonial pode ser dividida em duas fases: antes e depois de 1760. A primeira foi eminentemente jesuítica, embora seja discutível o aparente caráter exclusivamente privado da escola, face à união entre o Estado e a Igreja e aos favores oficiais concedidos aos inacianos. Mas, a partir da expulsão da Companhia, pela primeira vez, reconhecia-se de maneira inequívoca a educação como dever do Estado.

(AVELLAR, 1983, p. 161) 
Em outras palavras, se é verdade que havia uma íntima relação entre a Companhia de Jesus e a Coroa no que tange às atividades colonizadoras e que aquela tinha suas ações avalizadas pelo Estado português — o que pode caracterizá-las como estatais também é verdade que o que se passou na Amazônia, em meados do século XVIII, foi uma ruptura radical e inconciliável entre o Estado (representado pelo irmão do Primeiro Ministro) e os jesuítas.

Calmon (2002) esclarece a importância da Ordem dos jesuítas por serem responsáveis por amplo desenvolvimento nas colônias mesmo antes da instalação das Câmaras Municipais:

pertencem-lhe as primeiras estradas calçadas, as primeiras pontes, os cais, munidos de guindastes, as máquinas para a elevação de volumes nas barreiras, a organização das forças econômicas, com a hábil combinação da lavoura, da indústria agrícola e do comércio marítimo e terrestre. (CALMON, 2002, p. 120)

Wehling e Wehling (1999), ao tratarem da educação desenvolvida na colônia por parte da Ordem jesuítica, são enfáticos em apresentar dados importantes.

A educação foi, em grande parte, obra dos jesuítas. Os colégios da companhia de Jesus - 21 ao todo no século XVIII, mais sete seminários para a formação de sacerdotes - ensinavam gramática, aritmética e os demais estudos básicos. Os "reais Colégios" de Salvador e São Luís eram "Colégios de Artes", onde se estudavam filosofia e teologia em nível equivalente ao dos cursos superiores. (WHLING e WEHLING, 1999, p. 297)

Mas em meados do século XVIII, no Estado do Grão-Pará, se originou a perseguição aos jesuítas. Sendo Mendonça Furtado o principal comissário e plenipotenciário para a demarcação de limites na região, exigiu dos missionários das diferentes ordens todos os índios de serviço nas respectivas aldeias para acompanhá-lo na expedição ao Rio Negro, onde deveria encontrar-se com o comissário espanhol. De acordo com as leis vigentes, o Governador poderia exigir para seu serviço, a um só tempo, apenas a metade dos índios aldeados pelos religiosos, mas “míope e arrebatado como um déspota, nem curou da lei nem das conseqüências de violá-la" (SOUTHEY, 1981, p. 280). 
Com duração de cerca de um ano, a viagem desses índios na expedição de Mendonça Furtado resultou na ausência de mãos para o trabalho agrícola das missões e nas plantações de alguns colonos portugueses, causando fome em algumas aldeias. Por outro lado, a abolição do adiantamento do parco salário prometido aos indígenas (para serem evitadas deserções) e a irregularidade na distribuição da minguada ração, acabaram gerando enorme insatisfação entre os mesmos e a deserção acabou vingando em grande número.

Após esse evento o Governador enviou correspondência à Corte responsabilizando os jesuítas pela "trama diabólica" que fez com que os índios abandonassem suas obrigações para com o reino. A partir de então, as relações entre o Estado luso e os inacianos deixaram, definitivamente, de ser amistosas.

Uma obra importantíssima para se compreender melhor os acontecimentos da expulsão dos Jesuítas do reino português, sob um ponto de vista pró-jesuítico, é o texto do Padre José Caeiro, denominado "Sobre o Exílio das Províncias Transmarinas da Assistência Portuguesa da Companhia de Jesus Durante o Ministério do Marques de Pombal"'. Essa obra, escrita ainda no século XVIII (e prefaciada por outro jesuíta, padre Luiz Gonzaga Cabral em janeiro de 1935), expõe o ponto de vista dos inacianos a partir do relato de um contemporâneo dos fatos.

Em que pese ser o desvelado ódio que o autor destila em relação à Mendonça Furtado e Dom Miguel de Bulhões ${ }^{2}$ a força motriz de sua obra, esta, sem embargo,

\footnotetext{
${ }^{1}$ A referida edição na qual a leitura se baseia data de 1936, feita pela Academia Brasileira de Letras na Bahia e divide-se em três partes assim denominadas: Desterro dos Jesuítas da Província do Brasil, Expulsão dos Jesuítas da Vice Província do Maranhão e Preseguição [sic] aos Jesuítas da Província de Goa. Segundo está dito no prefácio do padre Luiz Gonzaga Cabral, este é um trabalho de fôlego do padre jesuíta José Caeiro, contemporâneo dos acontecimentos; escrito primeiramente em Portugal, e depois durante seu exílio na Itália, após sua deportação. Feito originalmente em latim, o texto foi traduzido pelo também jesuíta Manuel Narciso.

${ }^{2}$ Frei Miguel de BULHÕES, Bispo de Málaca, do Grão-Pará e de Leiria. Nasceu em Verdemilho (Aveiro) em 13 de agosto de 1706. Ignora-se a data da morte. Entrou na ordem dos pregadores do convento da Misericórdia de Aveiro, onde professou em 11 de outubro de 1723. Ditou Filosofia e Teologia aos seus confrades e foi um dos acadêmicos da Academia Real da História Portuguesa. Foi nomeado Bispo de Málaca em 8 de dezembro de 1746 pelo primeiro patriarca de Lisboa, D. Tomaz de Almeida. Dois anos depois, foi promovido para o Bispado do Grão-Pará e, em 1761, transferido para o Bispado de Leiria. Escreveu o SERMÃO DO AUTO DE FÉ, celebrado na igreja de São Domingos desta côrte, recitado em 6 de outubro de 1746. Lisboa, 1750. PASTORAL, datada de Leiria, 27 de maio de 1762; PASTORAL, datada de Leiria, 2 de abril de 1763; CARTA, datada do Pará, 21 de janeiro de 1752 (SWEET, 1983).
} 
representa uma importante fonte de informações sobre aquele período, sobretudo em se tratando das atividades dos jesuítas e do confronto destes com o governo do Estado.

A segunda parte da obra dedica-se a narrar os fatos ocorridos quando da expulsão dos Jesuítas do Estado do Grão-Pará e Maranhão, e divide-se em 21 (vinte e um) capítulos, cada um com suas devidas subdivisões.

O $1^{\circ}$ capítulo apresenta, em seis partes, a entrada dos jesuítas no Maranhão e seus primeiros trabalhos; a polêmica entre aliados de Paulo de Carvalho, tio de Sebastião de Carvalho e Melo (Marquês de Pombal) e a Companhia de Jesus e; finalmente, a crítica à figura do Bispo D. Miguel de Bulhões, tido como interesseiro, leviano e traiçoeiro.

Quanto à importância que os Jesuítas tiveram no processo de colonização das possessões portuguesas, diz o Padre José Caeiro:

Se todas as possessões portuguesas de álem-mar muito devem ás Províncias e padres da Companhia, nenhuma outra região, comtudo, Ihes deveria ser tão grata como o Maranhão; porque se êles nas outras terras extenderam e difundiram a influência portuguesa com os seus suóres e sangue, nesta foram êles que lhe lançaram o fundamento. Dentre todos foram os jesuitas os primeiros, que por montes e vales ousaram ir ter, em viagens de um ano, com aquelas gentes ferocissimas e habituadas a banquetearem-se com carnes humanas; e, lançar entre elas as sementes da religião, que regaram com seu sangue, fundamentando aquela nova colonia portuguesa. (CAEIRO, 1936, p. 309)

Apesar do esforço catequizador e dos serviços em prol da Coroa portuguesa nesta nova missão de sua maior colônia, para o autor do libelo anti-pombalino, a guerra contra os jesuítas já começara décadas antes do momento da expulsão definitiva, pois,

Durante 15 anos andou o Procurador das Camaras do Pará e do Maranhão, Paulo Nunes, recolhendo queixas, coligindo documentos e redigindo acusações e falsidades, que em 1755 serviram de armas para Carvalho arruinar a Companhia primeiro no Maranhão e depois em todo o mundo.

Já assim pensava havia mais de um século o célebre naturalista Martins, quando escreveu: "A história da supressão da Ordem dos jesuitas explicase quanto a Portugal pela posição por êles tomada nos negocios do Pará".

O mal destes jesuitas, escreveu o P. Burnichon, esteve em êles se anteciparem dois séculos á campanha anti-escravista do ultimo século. 
Teve assim começo nas terras do Maranhão a guerra contra a Companhia, que pelo Breve de Clemente XIV veio a sucumbir victima de calunias, origináriamente provocadas, por ela defender os seus irmãozinhos indios contra a crueldade dos brancos. (CAEIRO, 1936, p. 313)

O religioso, em sua obra, afirma que Carvalho e Melo valeu-se de alguns auxiliares em sua empresa para expulsar os Jesuítas de todo o reino. Além de não economizar críticas a esses adversários, Caeiro alimentava-as com argumentos pouco ortodoxos que atingiam inclusive a honra pessoal dos acusados.

Wehling e Wehling (1999) relatam que a instalação do sistema dos diretórios indígenas criado por Carvalho e Melo provocou sérias consequências para as missões, visto que

Consistiam na atribuição de um certo número de tribos ou aldeias a um diretor e outros funcionários, encarregados do ensino do português, do fomento à produção agrícola e comercial e do estímulo aos casamentos mistos. [...] Na prática o sistema funcionou precariamente, com abusos praticados pelos próprios diretores contra a mão-de-obra indígena, como a exploração em proveito próprio e a retenção dos salários. Isso contribuiu para o esvaziamento e a desarticulação das missões. (WEHLING e WEHLING, 1999, p. 321)

Junto com Pombal, outros dois personagens decisivos para o Estado do Grão-Pará no período em estudo são escolhidos como alvos principais de seu discurso. D. Miguel de Bulhões, Bispo do Pará, e Francisco Xavier de Mendonça Furtado, meio-irmão de Carvalho e Melo e governador do Estado, são protagonistas tão presentes na obra do Jesuíta quanto objetos de sua detalhada — e ácida — explanação.

O Bispo Bulhões era notoriamente um homem de confiança do Marquês de Pombal, a ponto de assim aparecer nas instruções régias que Mendonça Furtado recebeu ao ser escolhido como novo governador em 1751. Caeiro explica que isso era de se esperar, pois quando resolveu combater definitivamente os Jesuítas ele "começou por examinar quais seriam os personagens, que para êste intento melhor o poderiam auxiliar; e de todos o que mais apto Ihe pareceu foi o Bispo do Pará, Miguel Bulhões, dominicano, de quem convirá se conheçam os antecedentes, não indignos de serem conhecidos" (1936, p. 312). 
um homem de língua solta; e nem ainda quando prègava, a sábia moderar, chegando com isto a ofender ao rei $D$. João $V$ e aos seus Ministros. Correra fâma que se enamorara de uma religiosa, não sei qual; o certo e que de contínuo a costumava visitar e falar com ela, e que, não obstante o ter já sido por isto admoestado em nome do rei, ainda continuava a cartear-se diariamente com ela. Depois sendo já Bispo, costumava usar nos dias de festa um belíssimo cíngulo; e não corava de dizer aos presentes que êle fôra confecionado pelas mãos daquela mulher, a quem êle costumava chamar sua, e que ela lho déra como presente. (CAEIRO, 1936, p. 315-317)

Continuando sua caracterização do prelado, ele sustenta que o mesmo era dado a ser popular, exagerado no vestir e raro na piedade e, como Pombal já conhecia seu caráter, achou conveniente atraí-lo

para os do seu bando; nem isto se lhe antolhou coisa dificil, porque bem sabia que, acenando-lhe com a sua volta para Portugal ou com uma mitra melhor, logo o teria à sua disposição para tudo quanto lhe mandasse, e que êle, ou se tratasse de coisa justa ou injusta, não opporia dificuldade alguma em a pôr em execução. (CAEIRO, 1936, p. 325)

Quanto ao governador, são fartos os adjetivos utilizados pelo religioso. Para ele, Mendonça Furtado tinha pouco tino, a ponto de, quando souberam que tinha sido escolhido governador do Pará, todos em Lisboa ficaram admirados, pois tal homem, diziam, "deveria antes ir curar-se a uma casa de doidos".

Os seus costumes eram os da escola pombalina: nenhuma religião, nenhuma atenção para com os homens; e mais, era nele tanta a penuria, em que vivia, quanto a sua ambição de riquêsas. A isto acrescia a arrogancia, a soberba, a como congénita crueldade da gente carvaliana e o quasi incrível despudor em caluniar e mentir. Se Carvalho encontrasse em qualquer outro similhantes dotes, sem duvida o teria por muito digno para parceiro de Bulhões, e o escolheria para ambos levarem a cabo os planos que êle na mente andava volvendo. Assim que, encontrando-os todos e acrescidos em seu irmão carnal, e, podendo sem receio faze-lo participante de todos esses planos, começou logo a idear o modo como se Ihe poderiam confiar as redeas do govêrno do Maranhão. (CAEIRO, 1936, p. 327) 
Até a mudança da capital do Estado, de São Luiz para Belém, foi, para Caeiro, parte de um plano urdido para ludibriar o rei e consolidar o poder de Carvalho e Melo.

Com a chegada ao Pará do ex-promotor público do Maranhão, João Cruz, Mendonça Furtado passa a ter mais um aliado e, segundo Caeiro, começa a refletir sobre uma solução para o problema dos índios:

Poder-se-iam levar para o Maranhão colonos em grande numero, e repeti-los pelas aldeias, onde moravam os indios e, conseguindo isto, era fóra de duvida que estes indios, policiados com o trato dos portugueses, não só assimilariam facilmente os costumes destes, senão que contrariam o gosto pelas riquezas e pelo dinheiro, que ainda não têem. Por este modo tôda a vastidão das terras amazonicas se viria a povoar de cidades e vilas. (CAEIRO, 1936, p. 337-339)

Na verdade, a imigração de colonos para a Amazônia não tinha sido bem sucedida anteriormente e a resistência à empreitada havia crescido; deste modo, os escolhidos continuaram a ser aqueles sobre quem pendia algum tipo de pena. Por essa razão, Caeiro denunciou que "como não houvesse esperança de os fazer partir a bem, nem mesmo com premio, pois era de todos sabido o que acontecera aos antes levados das ilhas, insistiu Carvalho em que os fizessem ir á força, mas somente os criminosos" (CAEIRO, 1936, p. 341). É evidente também a insistência do autor quanto à frustrada tentativa, por parte de Mendonça Furtado, de "fundar no Maranhão um novo e amplíssimo império para a corôa lusitana" (CAEIRO, 1936, p. 335).

Caeiro arrola uma série de posicionamentos e eventos buscando comprovar o intento de expulsão dos inacianos, antes mesmo do atentado a D. José I, cuja maquinação Ihes foi atribuída pelo Marquês de Pombal.

Mais de uma vez em presença do Padre Domingos Pereira, exprobrou Mendonça aos jesuitas o "serem inuteis no Maranhão; quanto muito poder-se-ia tolerar, uma duzia para o colégio do Pará e outros tantos para o do Maranhão." A Domingos Serrano, do Pará, que de nenhum modo Ihe aprovara o seu modo de pensar, respondeu ele um dia: "Quando os jesuitas forem expulsos do Maranhão nenhum mal daí resultará para a cidade, mas antes muita utilidade." Ao voltar do Rio Negro para a cidade do Pará predisse êle em Gurupatuba, no dia 9 de dezembro de 1758, a um nobre português, por nome Pedro José da Costa, que na frota do ano seguinte embarcariam todos os jesuitas portuguêses para Lisbôa [...]. 
Quando no ano de 1756 aportaram no Pará novos jesuitas, vindos de Portugal, disse Mendonça, ao sabê-lo. a muitos presentes: "Para que vêem ainda para o Maranhão jesuitas portuguêses? Em breve do os Maranhão estarão de volta para Portugal."

Também a expoliação dos seus bens foi resolvida antes que ninguem sequer sonhasse na conjuração contra o Rei, a não ser o proprio Carvalho; e foi ela certamente comunicada a Mendonça, porque ao voltar êste do Rio Negro, bastantemente o deu a conhecer ao padre jesuita José Tavares que o hospedou em Jaguarary, dizendo-lhe que êle ia tirar as fazendas aos jesuitas. E o mesmo dissera a José Antonio Goes.

[...] Decretára-se, pois, a confiscação dos seus bens antes de começar a tal conjuração; e, consequentemente, ainda que não tivesse vindo ao mundo essa conjuração, os jesuitas haviam de ser desapossados dos seus bens. E também o seu exilio fôra resolvido ainda antes que Carvalho désse começo aos planos dela, como se demonstra pelo que acima dissemos. Teriam sido, portanto, expulsos os jesuitas ainda que os Tavoras não tivessem conjurado. (CAEIRO, 1936, p. 349-351)

As intransigentes críticas do jesuíta às iniciativas do governo português, no que tange ao sobredito conflito, não estão, todavia, isentas de contradições internas. Um dos esteios em que se baseia a defesa dos jesuítas por parte de Caeiro é justamente a luta intransigente destes pela liberdade e evangelização dos seus "irmãozinhos" índios. Entretanto, em algumas passagens de seu livro, o autor se permite expressar a verdadeira ideia que nutre a respeito dos nativos, quando desenvolve suas críticas ao Governo de Mendonça Furtado. O perfil do índio que é desenhado pelo padre apresenta-se, então, absolutamente diverso daquele que fundamenta a necessidade de salvação daquelas almas:

Para êste fim [Mendonça Furtado] reuniu na cidade quasi todos os indios das aldeias, sem excétuar os que pouco antes os jesuitas, com muito trabalho e muitos gastos, tinham descido dos montes, os quais, se por aqueles tempos se observassem as leis, deviam ficar dispensados de qualquer trabalho durante um bienio inteiro, já para nêste tempo se instruirem nos mistérios da religião, já para entretanto irem tomando gosto à terra e ao trato humano, antes de serem enviados a cultivar as fazendas dos portuguêses; porque é incrivel quanto aquela gente, propensa ao sôno e à ociosidade, tem horror a qualquer trabalho, [...]. [...] mas quando depois os encarregados dos trabalhos, entre os quais Mendonça era assíduo, começaram a fazer uso frequente tanto do chicote como das varas, contra os indolentes e preguiçosos quais êles costumam ser por natureza, e a acudir-lhes com um parco alimento, áquela gente, que é de um apetite devorador, também estes começaram tôdas as noites a fugir da cidade ás escondidas, regressando a pricipio para as suas aldeias, todos queixosos da durêza dos trabalhos, da tiranía dos senhores das fazendas e sôbretudo da escacez da alimentação. [...]. 
[...] Nada deixou entretanto de fazer por atrair e obrigar os corações dos caciques; e nem se enverganhava de receber á sua mêsa indios nus, sujos e de disposições repelentes em suas pessôas. (CAEIRO, 1936, p. 367, 369 e 405, grifo nosso)

Sonolentos, ociosos, indolentes, preguiçosos, comilões, sujos e repelentes, estes são os adjetivos utilizados por Caeiro para definir seus “irmãozinhos”. Mas nem tudo eram espinhos. Em diferentes momentos, Caeiro destaca o importante papel que a rainha Dona Mariana, tratada em seu texto como a "rainha austríaca", desempenhou como obstaculizadora das perseguições contra os jesuítas. Isso se dá especialmente a partir de 1755, quando, segundo ele, teve início a sucessão dos acontecimentos, pois já era falecida a soberana.

Até àquele ano pouco ou nada transpirára para o publico do que secretamente contra os jesuitas se urdia. Com as calúnias lançadas a público e as cartas enviadas ao Rei é que se começou a ativar o desterro dos jesuitas. E nenhum obstáculo se opunha às diligencias empregadas para êste fim, a não ser o animo da Rainha austríaca, muitissimo favoravel aos jesuitas maranhenses.

Vindo porém, ela a falecer no dia 14 de agosto de 1754, o fôgo, que ocultamente lavrara, se veio finalmente a atear com grande intensidade. E realmente logo Carvalho pela frota, que no princípio do ano seguinte, 1755 , se fez à vela para o Maranhão, avisou ao duum virato, Mendonça e Bulhões, Governador interino, que já dali em diante podiam declarar guerra aberta aos jesuitas, pois já em fim tinha desaparecido o maior obstaculo dela. (CAEIRO, 1936, p. 391)

A situação dos jesuítas já estava insustentável quando de sua chegada à metrópole, de modo que sua recepção foi digna de criminosos imigrantes.

Tendo os jesuitas dado à véla, expulsos do Pará a 9 de Setembro, aportaram a Lisboa, a 19 de Novembro, quando nela ainda estava fumegante o terrível incendio. E logo foram mandados saír para as residências fóra da cidade, para que, ou não podessem advogar as suas causas perante o Rei, ou não podessem delatar e testificar quanto contra a justiça e o direito se praticava no Maranhão. (CAEIRO, 1936, p. 393)

A título de considerações finais, Caeiro comenta, comparativamente, os resultados da ação dos jesuítas e os da ação dos diretores na aldeia de Javary: 
Estes num trienio fundaram a aldeia e a tornaram muito populosa: os novos diretores, apòs um outro trienio, fizeram dela, pelos seus processos, um ermo, como era dantes; e fizeram que no ano 1758 de tão bôa cidade, salvo as casas, que os jesuitas para si tinham edificado, nada tivesse ficado de pé; porque, voltando os selvagens para as suas matas, tudo o mais destruiram e incendiaram, afirmando e proclamando que "nenhum dos novos governantes os poderiam tão benigna e pacientemente suportar, e que não voltariam à aldeia senão com a condição de que os jesuitas (segundo Carvalho senhores déspotas e avarentos) também para lá voltassem". (CAEIRO, 1936, p. 403)

Quanto à criação da Companhia Geral de Comércio do Grão-Pará e Maranhão, Caeiro considera-a como resultado de uma bem armada trama de Carvalho e Melo para auferir para si os louros do florescente êxito econômico daquela região (CAEIRO, 1936). Nada mais equivocado. Em primeiro lugar, porque a suposta premissa de desenvolvimento do comércio no Estado durante o reinado de D. João V, "especialmente nos ultimos anos dele", é irreal. Em segundo lugar, porque aliada aos interesses econômicos da metrópole na região estava a necessidade da defesa militar.

No último capítulo $\left(13^{\circ}\right)$, da segunda parte do seu livro (referente à expulsão do Estado do Maranhão), Caeiro dedica-se a fazer uma "resenha das gentes barbaras, que os jesuitas conseguiram aldeiar, sem que a fazenda real para isto concorresse com alguma pequena soma". Trata-se da síntese de 37 anos de descimentos, fundações e povoamentos ${ }^{3}$.

$\mathrm{Na}$ verdade, a fazenda real concorreu com alguma quantia para sua povoação, apesar de o mesmo afirmar inicialmente que a Coroa não contribuiu com nada. Tal situação, embora se choque com a afirmação de que "os jesuítas financiaram nos primeiros séculos da história brasileira, com recursos próprios o sistema escolar e educacional por eles construídos" (BERGER, 1984, p. 197), nos dá uma ideia, ainda que incipiente, da gigantesca tarefa dos jesuítas, ainda mais quando se sabe da quantidade de recursos necessários para a implantação destes povoados. Diz Caeiro:

\footnotetext{
${ }^{3}$ Abacaxi (Serpa), Acarará (Monsão), Araticú (Vila de Oeiras), Arucará (Portel, "a mais populosa de todo o Brasil”), Aricará (Sousel), Aldeia maior dos barbados e Aldeia menor dos barbados, Bourari (Alter do Chão), Cumarú (Vila Franca), Santa Cruz, Caaby (Colares), Guaricurú (Melgaço), Guegués, Itacrussá (Vieiros), Itapycurú, Aldeia junto ao rio Magué (logo destruída e queimada pelos índios), Topina (Vila-Boim), Mataypú (Soutelto), Mortygura (Vila do Conde), Piraguyru (Vila de Pombal), Sumaúma, Tutoya, Taboca, Tapajós, Trocano (Nova Borba) (CAEIRO, 1936, p. 495-497).
} 
E pode-se bem avaliar a enormidade dos recursos precisos á obra dos jesuítas, pelo que passou com a aldeia de Myribira. Sendo as casas para um cento de moradores apenas, e não saindo ainda elas dos seus fundamentos, nem tendo siquer começado a egreja, já aquela aldeia havia custado á fazenda publica para cima de tres mil escudos romanos, se merecem fé os documentos publicos e a autoridade de Antonio Rodrigues Martim, guarda do tesoiro da nação. Se a administração dos jesuitas se assemelhasse á de Mendonça quanto a esta sua aldeia, em quanto importariam tantas, tão grandes e tão populosas aldeias, povoadas no espaço de 37 anos pelos jesuitas, ou inteiramente fundadas de novo ou de muitos modos melhoradas? E além disto quantos milhares de indigenas foram descidos e recolhidos nas aldeias? $\mathrm{E}$ mais ainda quantas igrejas, não só de novo edificadas, mas tambem largamente providas de tudo? (CAEIRO, 1936, p. 495-497)

Em uma reflexão acerca do trabalho jesuítico realizado ao norte da América portuguesa, Manuel Narciso Martins (tradutor da obra de Caeiro) faz uma oportuna comparação das aldeias do Estado do Grão-Pará com as do sul do continente chegando a uma conclusão surpreendente:

Se olharmos por outra parte ao estado de umas e outras enquanto à sua vitalidade, verificamos que as do Paraguay estavam nos ultimos anos da sua existencia quasi estacionárias; ao passo que as do Pará=Maranhão se achavam cheias de vida e iam tomando um desenvolvimento tal que podemos computar em quatro ou cinco mil indios os que anualmente se agregavam ao seio da greja [sic], quando delas desterraram os missionários.

Quanto ao numero das aldeias, ao serem extinctas as missões, sabemos que aquelas não iam alem de 30; emquanto as do Maranhão eram quasi o dobro, ou 55, espalhadas pelos matos do escoadouro do Amazonas e de outros rios (seus nomes podem ver=se no Atlas do P. Ludovicus Carrez, Paris).

Por aqui se vê a importancia, que iam já tendo aquelas missões, a todos os respeitos admiraveis da Vice-Provincia do Maranhão em 1755. E se não fôra o estulto golpe descarregado por Carvalho contra eles, aquelas regiões feracissimas até levariam em breve vantagem a quaisquer outras do Brasil, e hoje em prosperidade se avantajariam mesmo às de S. Paulo. (CAEIRO, 1936, p. 499) 


\title{
Os primórdios da instrução religiosa
}

No Estado do Grão-Pará, território integrante da América portuguesa, a instrução dos gentios, que teve nas Ordens religiosas seus primeiros protagonistas, foi, inegavelmente, o maior apoio que a Coroa portuguesa recebeu no processo de conquista cultural daquela população americana. Não podemos deixar de considerar, todavia, que se a vinda dos religiosos para o Grão-Pará tinha a intenção de colocar em prática um projeto de colonização, seus objetivos particulares (eclesiásticos) estavam acima de tudo, sendo garantida sua realização com a liberdade de atuação obtida na região amazônica, devido às suas características naturais favoráveis e à formidável possibilidade de acumulação de riquezas.

Para Rosário e Melo,

\begin{abstract}
a influência da educação jesuítica não se restringiu apenas ao período que por aqui se estabeleceram (1549 - 1759), ultrapassou períodos e, em todos eles encontra-se em menor ou maior quantidade reminiscências dessa educação [...].

Os padres jesuítas foram os primeiros professores do Brasil se a abordagem recair na chamada educação formal - escolarizada. Se consideramos que antes do chamado descobrimento aqui viviam outras pessoas, [...]; teremos necessariamente que considerar que antes da Companhia de Jesus, existiam outras educações, portanto, outras histórias da educação. (ROSÁRIO e MELO, 2015, p. 383)
\end{abstract}

A introdução da instrução dos gentios se fez dentro do contexto da colonização e serviu ao domínio europeu no Novo Mundo, visto que o acesso a essa região era extremamente difícil devido a fatores como clima, população e espacialidade; para facilitar a penetração na mesma, os religiosos foram chamados para dar início a essa aproximação. Deste modo, o trabalho das Ordens e Congregações religiosas teve inicialmente, duas finalidades principais, quais sejam: espiritual, perseguindo a conversão do nativo à religião cristã, e política, operacionalizando-se através dos aldeamentos, pois o fato dos nativos serem nômades dificultava o trabalho de catequização. Posteriormente, agregou-se a essas, a finalidade econômica, para que pudesse ser sustentado o custoso trabalho desenvolvido nas aldeias. Assim, a entrada dos missionários na Amazônia contribuiu efetivamente para a ocupação e fixação dos portugueses na região, sendo essa estabilidade, a base a partir da qual a Coroa e as 
Ordens procuraram abarcar novos espaços para a dilatação da fé e o consequente domínio lusitano.

Foi assim que no Pará colonial pré-pombalino - período que abrange 1616 a 1750 —, como em todo o Brasil neste período, a ação educativa ficou totalmente nas mãos dos religiosos que por aqui atuaram. A esfera secular nada de relevante fez pela educação no Pará durante esse tempo. O poder civil tinha sim, desde o início, uma preocupação com as riquezas da região, com impostos e com tudo que fizesse referência à fazenda (REIS, 1972, p. 23). Os militares tinham como loci privilegiados, os fortes, e vários eram os espalhados por toda a região, com a incumbência maior de fiscalizar o contrabando de mão de obra indígena e de riquezas regionais tais como as "drogas do sertão" por parte de estrangeiros (REIS, 1979, p. 18).

Nem autoridades civis, nem militares manifestaram, desde o início, qualquer interesse explícito ou iniciativas no sentido de desenvolver a instrução dos nativos, seja através de escolas ou de outros meios. Tal atividade restringiu-se ao programa de ação dos missionários católicos. No afã de cumprir esse ideário, os homens de Deus não pouparam esforços e, em um espaço de apenas 89 anos, desde a chegada dos primeiros religiosos a Belém, em 1617, instalando o Hospício do Una, o Pará contou com a presença de seis ordens religiosas católicas, a saber: os Franciscanos de Santo Antonio (1617), os Carmelitas (1626), os Mercedários (1639), os Jesuítas (1653), os Franciscanos da Piedade (1693) e os Capuchos da Conceição da Beira e Minho (1706) (MAUÉS, 1968, p. 20). Isso equivale a dizer que a cada 17 anos, em média, assistíamos a implantação de uma nova Ordem religiosa no Grão-Pará.

Num período que abrange 133 anos — que vai da chegada dos primeiros religiosos até a ascensão de Marquês de pombal —, existiram na Amazônia diferentes e variadas instituições educacionais, desde os colégios até os conventos, cujas orientações e esferas mantenedoras eram igualmente diversas, pois várias foram as instituições que, no GrãoPará e Maranhão, se voltaram para a transmissão e reprodução metódica de conhecimentos e comportamentos necessários à satisfação das exigências do projeto ocidental cristão ${ }^{4}$.

\footnotetext{
${ }^{4}$ Daí a grande preocupação em se comunicar com os nativos coroada pelo Padre Luís Figueira, que elaborou no Maranhão a Gramática e o Dicionário da "Língua Geral" (como era chamada o Tupi antigo ou
} 
Partindo da prerrogativa de que o Hospício do Una só se constituiu como um abrigo provisório dos primeiros religiosos e que ali não se desenvolviam atividades sistemáticas de ensino, é difícil definir qual a primeira instituição educacional criada no Grão-Pará. Entretanto, podem-se determinar dois marcos iniciais importantes: o Convento dos Franciscanos de Santo Antonio e o Convento dos Carmelitas, ambos construídos no ano de 1626.

Os carmelitas, chegados em 1626, fundaram o seu Convento, atual Colégio do Carmo (MAUÉS, 1968), onde eram ministradas aulas de teologia, filosofia e música, apesar de serem em caráter irregular, os dois primeiros cursos foram regularizados depois de 72 anos, com a transferência do curso permanente de São Luiz do Maranhão para Belém do Grão-Pará.

Em 1640, começa a funcionar em Belém, o Convento dos Mercedários, que aqui chegaram um ano antes, como escola aberta aos filhos dos moradores, a quem ensinavam por meio de aprovação real, gramática latina e bons costumes, além das primeiras letras. Na Vigia, também os mercedários construíram escolas e conventos com a finalidade educativa. Essa congregação foi extinta em 1787 por meio de uma bula papal (HOLANDA, 1985).

Os Jesuítas, chegados em 1658, foram os religiosos de maior influência na organização cultural do Estado do Pará através da sua ação educativa. Foram os que fundaram o primeiro curso superior regular do Pará, além de possuírem 35\% de todos os aldeamentos existentes no estado até o ano de 1750.

Segundo Rosário e Melo,

os jesuítas, atuaram como verdadeiros "soldados" de cristo na educação e no ensino. Na Europa ensinaram em seminários, colégios e universidades objetivando recuperar a antiga posição da Igreja Católica Romana, enquanto nas áreas recém-descobertas organizaram, além, do trabalho educacional, as missões, com o intuito de conquistar e preservar para a Igreja Católica os povos que não foram atingidos pela expansão protestante. Neste sentido, os jesuítas exerceram no Brasil um destacado papel, tanto na educação como na catequese do índio e dos colonos. (ROSÁRIO E MELO, 2015, p. 384)

Tupinambá), editados em 1621 e que foram de muita valia no trato dos religiosos com os índios. 
Esta Ordem construiu o Colégio Santo Alexandre, atual sede do Arcebispado, primeiro colégio da Amazônia, onde eram ministradas aulas nos níveis primário, secundário e superior. Este último, de caráter regular, iniciou-se em 1695 com o curso filosófico-seminarístico e conferia aos alunos o diploma de Bacharel, licenciado e Mestre em Artes, não obstante o curso se voltasse para a formação de novos religiosos.

Outro importante colégio dos jesuítas na região foi o Colégio da Mãe de Deus, instalado na cidade da Vigia em 1732, que lecionava aos moradores daquela vila aulas de latim, primeiras letras, as quatro operações e música; além de filosofia racional, moral e outras disciplinas necessárias ao sacerdócio. Possuía ainda uma biblioteca com 1010 volumes (ILDONE, 1991).

No início do século XVIII, tivemos no Pará a construção de dois novos conventos: o primeiro, logo no início do século, é o de São Boaventura dos Capuchos da Conceição da Beira e Minho. Sua ação educativa, embora existente, é muito curta, visto que em 1716 o espaço do convento já é utilizado para servir de abrigo às "Casas das Canoas", atualmente Arsenal da Marinha. O segundo, construído por volta da quarta década, é o de São José dos Franciscanos da Piedade, espaço que foi ocupado pelo "Presídio São José", hoje denominado "Polo Joalheiro São José Liberto". Pouco temos sobre a ação educativa desenvolvida por esses dois conventos, mas é de se supor que ambos, por participarem de uma regra geral - o interesse dos religiosos pela educação neste período — devam ter desenvolvido algum tipo de atividade educacional.

\section{A ação dos jesuítas e o protagonismo de Antonio Vieira}

A Companhia de Jesus tem seus fundamentos baseados em uma rígida disciplina, caracterizada pela origem militar de seu fundador Santo Inácio de Loyola. O mesmo converteu-se ao catolicismo a partir de um período de convalescença em que se encontrava, decorrente dos ferimentos por ele adquiridos numa batalha em que lutava como soldado, por volta de 1523. Apesar de existirem outras ordens religiosas na Amazônia no período anterior à entrada dos Jesuítas, estes conseguem desenvolver um trabalho bem mais intenso e consistente. 
A organização da Companhia de Jesus estava de tal forma estruturada, que seus membros dispensavam os fundamentos usuais da vida em comunidade: o individualismo da época impregnou-a e foi por ela colocado a serviço da religião de modo tal que onde houvesse um Jesuíta haveria uma ordem. Caracterizando-se, essencialmente, pela rígida disciplina militar a que se submetiam os seus membros (MAUÉS et al., 1968).

A existência da mão de obra escrava indígena na região, como uma imposição dos colonos para o crescimento econômico dos seus negócios, não era algo apreciado pelos padres da Companhia, e isso significava um grande empecilho para a autorização da sua missão na Amazônia. O impasse precisava ser vencido, e o foi, a partir de um acordo assinado entre a Câmara de Belém e os Jesuítas.

Entretanto, no ano de 1636 chega ao Pará o padre Jesuíta Luis Figueira, na companhia do Governador Francisco Coelho de Carvalho. O padre viajou pelo interior examinando as possibilidades de implantação da missão na Amazônia e retornou à Europa, defendendo a criação de uma missão jesuítica na Amazônia diante do Conselho Ultramarino. O referido Conselho, depois de examinar a solicitação defendida pelo jesuíta, "mais de uma vez tendo tido necessidade de explicar e insistir em tôrno ao que lembrava, mandara promover a série de providências, encarregando Luis Figueira do empreendimento catequista com a Companhia de Jesus" (REIS, 1979, p. 22).

Após essa vitória dos Jesuítas, no ano de 1645 deu-se o retorno do Padre Luis Figueira ao Pará, com mais alguns acompanhantes, para então iniciar o trabalho de catequese. Entretanto, uma fatalidade impediu a implementação imediata da Companhia de Jesus na Amazônia. Foi o naufrágio da embarcação que os trazia, nas proximidades da Baía do Sol, sendo que alguns desses padres conseguem sobreviver e atingir a terra, contudo, foram mortos pelos índios Aruans, do Marajó.

Somente em janeiro de 1653 ocorreu, de fato, o estabelecimento da Companhia de Jesus na Amazônia, com os padres João de Souto Maior e Gaspar Fragoso, na companhia do Capitão-Mor Inácio do Rêgo Monteiro.

Calmon explica que

a autoridade eclesiástica era isenta do foro civil; foi isto suficiente para que as duas administrações - a Igreja e o Estado - colidissem nas suas 
órbitas de ação e de contínuo transformassem em conflitos ásperos os choques de jurisdição. Desde o primeiro bispo, os governadores eclesiásticos procuraram limitar a alçada dos governadores civis, que, por seu lado, não fugiam de perturbar os negócios religiosos com a sua intervenção indébita. Queixavam-se mutuamente para o reino, faziam prosélitos entre os colonos, ameaçavam-se, e à tranqüilidade dos povos. (CALMON, 2002, p. 148)

Quando esses religiosos chegaram à Amazônia, sua primeira instalação se deu no bairro da Campina, em terreno cedido pelos padres Mercedários. Neste local, construíram casa e capela de palha. Como ficava distante do núcleo populacional, os Jesuítas entraram em negociação com a Câmara de Belém para conseguirem terreno nas proximidades do forte. Assim, apresentaram à Câmara carta enviada pelo rei D. João IV, dizendo o seguinte:

Eu El-Rei vos envio muito saudar. Ordenei aos religiosos da Companhia da Província do Brasil, que, por serviço de Deus e meu, tornassem a êsse Estado e fundassem nêle as igrejas necessárias com o intento de doutrinar e encaminhar ao gentio dêle a abraçar nossa Santa Fé, principal obrigação minha nas conquistas. E, porque lhes será de grande ajuda vosso favor e assistência, vos encomendo muito e mando que lha deis em forma que tenha eu muito que vos agradecer [...] (LEITE, 1943, p. 208)

Esse documento representava a autorização que a Companhia de Jesus necessitava para iniciar o processo de catequização. Todavia, sua presença na região se mostrava desagradável aos colonos lusos e isso ficou bem claro quando a Câmara de Belém negou a primeira solicitação para eles se fixarem na Amazônia. Entretanto, com a carta enviada pelo rei, os Jesuítas não só conseguiram a autorização que pleiteavam, como igualmente demonstraram, desde a sua chegada, seu grande poder político.

Vale ressaltar que mesmo com a carta enviada pelo rei, só foi possível a permanência da Companhia de Jesus devido a um termo de compromisso assinado pelo Padre Reitor.

Aos 26 dias do mês de Janeiro de 1653 anos, nesta cidade de Belém, Capitania do Grão-Pará, estando presentes os oficiais da Câmara, e o Padre Reitor João de Souto-Maior que vinha fazer casa para ensinar a Doutrina e latim aos filhos dos moradores, pelo procurador do Conselho foi dito que não havia de entender com escravos dos brancos, a que o dito Padre Reitor disse, que êle queria assinar o dito têrmo de em tempo 
nenhum entender com escravos de brancos, nem ainda queria administração de índios forros, mas quer ensinar-lhes a Doutrina, e que para isso levava muito gôsto, que êste termo se fizesse; e declarou mais, que esta obrigação ficava nos mais, que viesses a suceder-Ihe. E assinou com os ditos oficiais. (LEITE, 1943, p. 209)

Os Jesuítas aceitaram assinar o termo, pois isso significava a garantia definitiva da sua permanência na Amazônia. Após esse ato, conseguiram um terreno nas proximidades do forte, agora bem no centro do núcleo populacional, onde deram início à construção da igreja de São Francisco Xavier e do Colégio Santo Alexandre. A partir de então, a influência dos Jesuítas passou a ser tão grande que, de acordo com Leite, o forte passou a ter a denominação de "Forte do Colégio", por influência do Colégio Santo Alexandre que começava a ser erigido (LEITE, 1943).

Calmon ao tratar da educação na colônia explica que a

instrução era jesuítica. Só os jesuítas fundaram colégio ("colégios" e "residências" chamavam-se as suas casas), só eles tinham "classes", donde serem "clássicos" os autores aí estudados, só eles ministravam o ensino elementar, de acordo com o Ratio Estudiorum, que modificara o método da Universidade de Paris - ensino integral, concêntrico, progressivo, aristotélico, igualmente de humanidades, moral e ginástica. (CALMON, 2002, p. 134)

Com a chegada do padre Antônio Vieira, superior da missão no Estado do Maranhão e Grão-Pará à capitania do Pará, no ano de 1654, a ação dos Jesuítas tomou novo impulso, intensificando-se cada vez mais na região e tomando outros condicionantes para o trabalho missionário. O mesmo viajou pelo interior com a finalidade de examinar as condições em que se encontrava o trabalho missionário da Companhia de Jesus. A partir dessa observação, deixou elaborado um plano de atuação para os Jesuítas na Amazônia visando à solidificação e expansão da catequese indígena.

No ano de 1655, o padre Antônio Vieira retorna à Amazônia, para observar os resultados do que foi previamente elaborado. Nesse período, destaca-se a catequização de índios considerados perigosos, devido à forte resistência para com o trabalho missionário, bem como a criação de várias aldeias no interior da região.

No ensino jesuítico, os professores nem sempre eram padres, pois eles eram 
poucos e se dedicavam mais às aulas de conteúdo mais complexo, às expedições ou aos cargos de governo. O padre Serafim Leite dedica o $2^{\circ}$ capítulo do $5^{\circ}$ livro do tomo IV de sua obra ${ }^{5}$ à narração dos feitos dos Jesuítas no Pará no que se refere aos "estudos". Dividindo o capítulo em quatro partes, inicia tratando da instrução primária e, insuspeito, afirma que "A instrução inicial no Pará foi também mais instrumento de catequese do que pròpriamente ramo profissional de ensino" (LEITE, 1943, p. 271).

Para Rosário e Melo

os padres jesuítas foram os maiores responsáveis pela catequese do índio, construindo um imenso patrimônio em gente, terras e rendas. Além de converter os nativos ao catolicismo, batizando-os, mudando seus hábitos e ensinar-Ihes a língua portuguesa, os jesuítas se tornaram agentes de aculturação indígena pela civilização cristã ocidental. Isso fragilizou - os e os transformaram em presa fácil dos colonos que, apesar da oposição dos padres, invadiam as missões e escravizavam os nativos já fragilizados, facilitaram assim, a expansão do domínio português. (ROSÁRIO e MELO, 2015, p. 385)

O Padre Antônio Vieira esteve presente no Grão-Pará em meados do século XVII e encontrou-se com outros educadores Jesuítas, dentre eles, o padre João Felipe Bettendorff — que relata em sua conhecida "Crônica" um fato que nos dá ideia da rusticidade do ensino naquela época e naquele lugar:

Em esta aldêa de Murtigura, tendo o Padre Subprior e visitador Antonio Vieira despedido o Padre Manoel Nunes e o Padre João Maria Gorsony para os Ingaybas, e mandando ficar-me a mim por companheiro do Padre Francisco da Veiga para aprender a lingua, ensinando o $A B C$ aos meninos, voltou-se para o Pará [...] juntaram-se muitos discipulos e entre eles o capitão Jacaré; e são estes hoje os mais autorizados e velhos da aldêa (os meus discipulos) e por que, por falta de livros tinta e papel, não deixassem de aprender, lhes mandei fazer tinta de carvão e summo de algumas ervas, e com ella escrevia em as folhas grandes de pacobeiras e para Ihes facilitar tudo lhes puz um páuzinho na mão por penna, e os ensinei a formar e conhecer as letras assim grandes como pequenas no pó e arêa das praias, com que gostaram tanto que enchiam a aldêa e as praias de letra [...] (BETTENDORFF, 1990, p. 156-157)

\footnotetext{
${ }^{5}$ A obra História da Companhia de Jesus no Brasil está dividida em dez volumes, co-editada em 1943 pela livraria Portucália, de Lisboa e pelo Instituto Nacional do Livro, do Rio de Janeiro.
} 
Na medida mesma em que os padres faziam progredir seu trabalho educativo com os nativos, conhecendo cada vez mais sua cultura, acercando-se dos seus conhecimentos e seduzindo-os à sua influência, aumentavam seu poder de interferência na região. Tal se deu com maior intensidade, pois a própria Coroa entregou aos missionários, notadamente aos jesuítas, o controle - ainda que questionado por colonos — sobre as aldeias indígenas.

Um componente decisivo para a atuação religiosa foi a língua ensinada aos índios aldeados. Àqueles que "desciam” para as missões era dado aprender uma língua estranha, tanto aos seus padrões como aos dos próprios colonizadores, resultado que era da mistura entre o tupi e o português:

A gramática dos missionários é toda artificial e não natural. Com effeito si não crearam os vocábulos da língua, modificaram-lhe a syntaxe e a prosodia, estabelecendo uma construção grammatical á latina e uma orthographia especial, que se perpetuou, mascarando a verdadeira pronúncia indígena e alterando a maneira de seu falar. (RODRIGUES, 1888, p. 107)

Prova inconteste da crença que os jesuítas tiveram na força da linguagem para o desenvolvimento do seu trabalho evangelizador, a língua criada — nheengatu — impôsse como um privilegiado canal de comunicação entre os que dividiam o espaço amazônico, seja como colonizado, seja como colonizador.

Para os eclesiásticos, isso significou um imenso espaço aberto para suas obras catequéticas, daí advindo o grande número de aldeamentos espalhados pelo novo Estado, o que configurou a primeira metade do século XVIII como uma autêntica fase de florescimento das missões religiosas.

Naqueles anos, o que se observa é que, até sua primeira metade, experimenta-se a expansão das atividades dos religiosos pelo interior do estado, destacando-se nesse processo, os religiosos da Companhia de Jesus. Estes edificaram sua primeira igreja em Vigia, no ano de 1702; tal obra veio acompanhada da abertura de colégios $^{6}$ e aulas de

\footnotetext{
${ }^{6}$ Este é o quadro de colégios jesuíticos elaborado por Hélio Abranches Viotti (apud FERNANDES, 1980, p. 6465): I- Colégios com estudos gerais, ou curso de Artes pelo menos: 1. Real Colégio de Jesus, Bahia, 1560. Aí, após 1560, com Luís da Grã, se iniciaram as Humanidades. Desde 1567, a Teologia Moral, com Quirício Caxa. Desde 1572, os cursos de Artes de Teologia Dogmática, com Gonçalo Leite e Quirício Caxa, por iniciativa de
} 
latim.

Continuam a chegar religiosos e, em 1720, temos o primeiro curso de filosofia e teologia que, transferido do Maranhão para Belém, funciona como colégio no Convento do Carmo. Em 1752, segundo Antônio Baena (1969), o Bispo do Pará estabelece o Seminário Eclesiástico com base em Alvará de 1751 e submete sua administração aos Jesuítas.

Em Carta Régia enviada pelo rei D. José ao governador Mendonça Furtado, em 1751, é perceptível a autoridade eclesiástica na região sobre os índios:

Como à minha real notícia tem chegado o excessivo poder que têm nesse Estado os Eclesiásticos, principalmente no domínio temporal nas suas aldeias, tomareis as informações necessárias, aconselhando-vos com o Bispo do Pará, que vos instrua com a verdade a qual dele confio, por ter boa opinião da sua prudência e letras e pela prática que já tem do país, para informardes se será mais conveniente ficaremos Eclesiásticos somente com o domínio espiritual, dando-se-lhes côngruas por conta da minha Real Fazenda, para cujo fim deve-se considerar o haver quem cultive as mesmas terras, do que fareis todo o exame para me informardes, averiguando também a verdade do fato a respeito do mesmo poder excessivo e grandes cabedais dos Regulares; e em tudo isto deveis proceder com grande cautela, circunspeção e prudência, fazendo, entretanto, observar, com grande acuidade e exação a liberdade dos índios, como nesta Instrução vos ordeno, para que assim disponhais os ânimos dos moradores desse Estado, para que removam de sua idéia os injustos cativeiros e o bárbaro modo com que até agora trataram os índios; e procurareis por algumas pessoas, de que fizerdes

Inácio Tolosa. Era o Colégio Máximo da Província. 2. Real Colégio de Santo Inácio, Rio de Janeiro, 1567. No século XVIII ombreava com o Colégio da Bahia e se preparava para ser o Colégio Máximo na nova província a ser criada no Sul do Brasil. 3. Real Colégio de N. Sa. Da Graça, Olinda, 1573. 4. Colégio de São Paulo (depois de Santo Inácio), São Paulo de Piratinga, 1554, restaurado em 1653. 5. Colégio de Jesus, Recife, 1678. 6. Colégio de N. Sa. . Da Luz, São Luís do Maranhão, 1679. 7. Colégio de Santo Alexandre, Belém do Pará, 1681. II- Colégio sem Curso de Arte: 8. Colégio de São Miguel, Santos, 1643. 9. Colégio de São Tiago, Vitória, 1654. 10. Colégio de São Gonçalo, Paraíba, após 1685. 11. Colégio N. Sa. Da Assunção, Ilhéus, 1720. 12. Colégio da Madre de Deus, Vigia do Pará, 1732. 13. Colégio de N. Sa. Do Terço, Paranaguá, 1752. III- Colégios em fase de consolidação: 14. Colégio do Salvador, Porto Seguro, 1611. 15. Colégio de N. Sa. do Pilar, Tacuitapera (Alcântara), 1716. 16. Colégio de São Francisco Xavier, Colônia do Sacramento, 1717. 17. Colégio de N. Sa. do Desterro, (Florianópolis), 1752. Além dos colégios acima mencionados, ou externatos gratuitos, mais os seguintes seminários, ou seja, internatos: I- De formação na exclusivamente sacerdotal: 1. Seminário de Belém, Belém da Cachoeira, 1730. 2. Real Hospício de Aquiraz, Ceará, 1739. 3. Seminário de N. Sa . Das Missões, Belém do Pará, 1749. 4. Seminário de Aldeias Altas, Caxias (MA), no qual se fundiram os da Paraíba (1749), de Guanaré e Simbaíba (1753). Il- Estabelecimentos para exclusiva formação de sacerdotes: 5. Seminário de N. Sa. Da Conceição, Salvador (BA); início em 1736, com Malagrida; em 1747, em funcionamento; novo edifício, à Rua Maciel de Baixo, em 1756. 6. Seminário de N. Sa. Da Boa Morte, Mariana, 1750; fundado por Dom Manuel da Cruz; mas sob direção dos jesuítas (PP. José Nogueira e Manuel Tavares, até 1757). 7. Seminário de São Luís, São Luís do Maranhão, 1753. III- Seminários anexos a Colégios: 8. Seminário da Paraíba, 1745. 9. Seminário de Paranaguá, 1755. 10. Seminário de São Paulo, 1757. 
alguma confiança, persuadir aos mesmos moradores quanto lhes é mais útil terem homens, que gostosa e voluntariamente os queiram servir e não, como até agora, violentos, que não cuidam senão em fugir, desamparando-lhes as suas fazendas, sem se interessarem na utilidade delas. (apud MENDONÇA, 2005, p. 72)

Os Jesuítas iniciavam, nesse momento, a edificação e sedimentação de um projeto que perdurou por mais de um século, tendo inicialmente o total apoio da Coroa Portuguesa. O poder político e, consequente poder econômico desses religiosos, começa a ter dimensões grandiosas, a ponto de, em 1686, passarem a exercer o governo espiritual e temporal das aldeias através do Regimento das Missões. No campo econômico, acumularam riquezas em diferentes cantos da rica região.

\section{Vieira e a liberdade dos índios}

Vieira foi, inegavelmente, o mais ilustre defensor da liberdade dos índios, além de brilhante intelectual e hábil negociador. Não se pode falar dos Jesuítas durante o século XVII sem mencionar seu nome; sobretudo por se tratar de um eminente representante da Companhia, que viveu por um significativo período no Estado do Grão-Pará e Maranhão (naqueles tempos, denominado apenas de "Maranhão").

Sobre a importância que tinha Antônio Vieira para a cultura luso-americana, vale a pena emprestar de Meihy a compilação de adjetivos atribuídos ao jesuíta:

A respeito deste jesuíta dom Francisco Manuel de Melo referia-se como "o maior pregador de todos os tempos"; o padre Feijo, ácido crítico dos exageros barrocos, o elogiava como "lúcido solitário", e ao mesmo tempo o padre Isla o assumia como "modelo". Fernando Pessoa reconhece em Vieira "o imperador da língua portuguesa" enquanto o historiador Charles Robert Boxer distingue nele "a mais importante figura do mundo luso-brasileiro no século XVII". João Francisco Lisboa, dos escritos vieirenses diz "engenho novel de extraordinário vigor", enquanto Hernani Cidade admirava-se com esse "mago e famigerado utopista". Alfredo Bosi reiventa sua imagem e o descreveu dizendo que "seus olhos negros e vivíssimos, cercados de olheiras profundas, eram olhos postos no futuro", e, realísticamente, Anita Novinsky conclui que "não obstante o lutador, Vieira foi um perdedor". Acima do amor e do ódio freqüentes e exaltados, independentemente de suas vitórias e insucessos, António Vieira foi aclamado por todos como grande, diria mesmo de imensidão vasta tanto quanto o Império. (MEIHY, 1992, p. XV$\mathrm{XVI})$ 
Maxime Haubert também reitera a importância do honorável padre que "dedicou toda uma vida turbulenta, agitada e atormentada por mil provações a defender 'seus' índios contra a escravidão e os rigores, [...] incansável denunciador dos abusos, ele não recua, como Las Casas, no México, diante de excessos e contradições" (HAUBERT, 1990, p. 13). Bosi, leitor e admirador confesso de Vieira, reforça sua grandeza como, “conselheiro de reis, confessor de rainhas, preceptor de príncipes, diplomata em cortes européias, defensor de cristãos-novos e com igual zelo missionário no Maranhão e no Pará, Vieira traz em si uma estatura e um horizonte internacional” (BOSI, 1992, p. 119).

Na sua luta em defesa da liberdade dos índios, o padre Antônio Vieira redige inúmeras cartas à Corte portuguesa. Em uma delas, cujo intento era "mostrar a pouca justiça com que foram julgados por cativos setecentos e setenta e dois índios do Maranhão" (VIEIRA, 1992, p. 3), ele se refere às leis e ordens do rei sobre a liberdade e cativeiro dos índios do Maranhão, lembrando que a primeira lei relativa aos indígenas "Se observa desde o ano de 1595, em que se passou a primeira lei em tempo del-rei Filipe II, a qual lei depois foi confirmada por todos os reis que lhe sucederam" (VIEIRA, 1992, p. 4).

Entretanto, de muito pouco serviria este instrumento régio. Injuriado ele combate os "excessos" cometidos contra os índios e relata que o rei, em 1652, manda "que no estado do Maranhão e Pará se observassem e executassem as leis e ordens acerca da liberdade e cativeiro dos índios" (VIEIRA, 1992, p. 4). Tal não adiantou, graças à pronta reação dos poderosos da região, chegando ao Estado uma lei que revia a questão, estabelecendo novas bases para o cativeiro dos indígenas. Sobre isso, Vieira informa que “chegou esta nova lei ao Maranhão e Pará no ano de 1654, e foi recebida com tanto contentamento e aplauso de todos, e tão estimada por larga e favorável, que mal se podia esperar que a não guardassem" (VIEIRA, 1992, p. 5).

A batalha não acabou aí. Em 1655, os defensores da liberdade dos índios novamente conquistariam uma vitória, pois o rei mandaria revogar e declarar por nula a sobredita lei e "mandou fazer uma nova e última lei na qual, pelas causas nela alegadas, resolve sua majestade, que no estado do Maranhão se não possam cativar índios" (VIEIRA, 1992, p. 7).

Segundo Beozzo (1983), esta lei se constitui no primeiro Regimento das Missões (lei de 9 de abril de 1655), que passaria a regulamentar a prática missionária na Amazônia. 
Para ele, o documento fundamenta-se basicamente em três pontos: o primeiro refere-se à necessária pacificidade com que se deve tratar os índios; o segundo, ao tipo de servidão que cabe aos índios e o terceiro - no qual se localiza a novidade — trata das missões no sertão, com independência das autoridades locais.

Outra Lei Régia, a de 12 de setembro de 1663, modifica mais uma vez o quadro, pois agora entregava a administração temporal das aldeias a capitães seculares nomeados pela Câmara, cabendo aos missionários apenas sua dimensão espiritual.

Em $1^{\circ}$ de dezembro de 1686, outro Regimento seria baixado e denominado "Regimento das Missões do Estado do Maranhão e Grão-Pará". Toda essa legislação, todavia, não foi o bastante para conter a sanha escravista dos colonizadores.

É justamente por causa de sua luta e do respeito que desfrutava que, em 1678, Vieira escreve um informe em resposta ao Conselho Ultramarino quando questionado acerca do Grão-Pará e Maranhão. Neste documento, o jesuíta faz uma análise da situação política e econômica do Estado, ao mesmo tempo em que propunha uma série de medidas para "ressuscitá-lo".

Vieira corrobora o ponto de vista do governador quando este reclama da carência da mão de obra necessária ao desenvolvimento econômico do Estado e de braços para sua defesa ${ }^{7}$. Todavia, não poupa críticas à forma como vêm sendo tratados os índios e denuncia constantemente os maus-tratos expondo em seu texto dados aterradores acerca do genocídio perpetrado aos nativos:

Sendo o Maranhão conquistado no ano de 1615, havendo achado os portugueses desta cidade de S. Luís até o Gurupá mais de quinhentas povoações de índios, todas muito numerosas e algumas delas tanto, que deitavam quatro a cinco mil arcos, quando eu cheguei ao Maranhão, que foi no ano de 1652 , tudo isto estava despovoado, consumido, e reduzido a mui poucas aldeolas, de todas as quais não pôde André Vidal ajuntar oitocentos índios de armas, e toda aquela imensidade de gente se acabou ou nós a acabamos em pouco mais de trinta anos, sendo constante estimação dos mesmos conquistadores que, depois de sua

\footnotetext{
${ }^{7}$ O eminente jesuíta percebia - como o governador - um estado de miséria naquele território: a causa da sobredita miséria é a falta de índios, assim livres como escravos, sem os quais os moradores se não podem sustentar nem aplicar à cultura das novas drogas, de que a terra é capaz, e muito menos defender-se em ocasião de inimigos, por serem os portugueses poucos, os portos e lugares por onde podem ser invadidos muitos, e a costa vastíssima, aberta, e sem defesa (VIEIRA, 1992, p. 85).
} 
entrada até aquele tempo, eram mortos dos ditos índios mais de dois milhões de almas [...] (VIEIRA, 1992, p. 86)

O jesuíta identifica sem meios-termos a sanha exploratória e a cobiça desmedida dos colonizadores (sem poupar os religiosos) como a razão de tanta destruição e assassinatos:

\begin{abstract}
Seja a última máxima a causa única e original de toda esta destruição e miséria, a qual não foi nem é outra qua a insaciável cobiça e impiedade daqueles moradores e dos que lá os vão governar, e ainda de muitos eclesiásticos que, sem ciência nem consciência, ou julgavam por lícitas estas tiranias ou as executavam, como se o fossem, não valendo a muitos dos tristes índios o serem já cristãos ou vassalos do mesmo rei, para não Ihes assaltarem suas aldeias e as trazerem inteiramente cativas [...] (VIEIRA, 1992, p. 87)
\end{abstract}

Em paralelo às críticas que fazia contra a perseguição aos índios, inúmeros exemplos de desprendimento por parte dos Jesuítas são narrados em detalhes. Em resposta às acusações de que os padres não faziam mais Missões, Vieira descreve com razoável precisão algumas atividades de descimento ${ }^{8}$ desenvolvidas pelos mesmos na região, como testemunho da sua natureza evangelizadora e como provas incontestes do importante trabalho missioneiro por eles realizado.

Além dos já abordados, o eminente jesuíta discorre sobre vários outros assuntos no referido documento, chegando a opinar sobre a organização política e a introdução da moeda, embora afirmando não se atrever "a dar juízo" sobre este último tema.

Finalizando seu informe, Antônio Vieira (1992, p. 94) atribui elegantemente “o milagre de ressuscitar o Estado do Grão-Pará e Maranhão ao poder de sua alteza e o maduro e acertado conselho de seus ministros". Entretanto, não se furta a apresentar 7 (sete) meios para o sucesso da empreitada.

Defendendo explicitamente a escravidão dos negros, sua primeira sugestão é que:

Sua alteza por conta de sua real fazenda, pois não há particulares que o façam, mande meter no Maranhão competente número de escravos de Angola, os quais se vendam por preço moderado aos moradores, e com

\footnotetext{
${ }^{8}$ Assim era chamado o processo de transporte de índios (aprisionados e/ou catequizados) do sertão para as aldeias colonizadas.
} 
largueza de tempo em que os possam pagar pelo rendimento dos gêneros que fabricarem. (VIEIRA, 1992, p. 98-99)

O segundo destes meios sugere "Que o resgate ou latrocínio dos índios chamados escravos totalmente se proíba", ao mesmo tempo em que propugna um castigo para quem o desrespeite (VIEIRA, 1992, p. 98-99). O terceiro meio advoga o cuidado e a proteção do rei para com as aldeias convertidas, onde "Nem os índios nem seus párocos sejam molestados dos moradores" (VIEIRA, 1992, p. 98-99). A quarta sugestão de Vieira para solucionar o caso diz respeito ao descimento dos índios, sempre por meio dos missionários, pacificamente e sem violência e à ocupação destes nas aldeias em que venham habitar (VIEIRA, 1992, p. 99-100). Nos meios restantes $\left(5^{\circ}, 6^{\circ}\right.$ e $\left.7^{\circ}\right)$, percebe-se sua preocupação com a administração desses índios - que para ele deveria ser responsabilidade dos religiosos; com a repartição dos mesmos pelos moradores somente após serem fornecidas e povoadas as sobreditas aldeias e, finalmente; com a situação de trabalho de "Velhos e mulheres e moços das aldeias, incapazes de irem ao sertão" (VIEIRA, 1992, p. 100).

Como é possível perceber, para o imaginário pombalino a “República Missionária”, profundamente enraizada no modo de vida dos índios, com uma dinâmica própria de exercício de poder e arredia ao projeto disciplinador oficial, incomodava as contínuas reformas políticas governamentais, cujos desígnios estavam dirigidos para soluções sociais e econômicas estáveis e submissas à Corte.

\section{Considerações finais}

O sentido, e o desejo político, de amputação do poder jesuítico, que era ao mesmo tempo eclesiástico e temporal — pois com suas influências religiosas, acabavam por fomentar uma espécie de "Estado paralelo" — baseavam-se na necessidade de impedir a manutenção das vantagens e a autonomia daqueles que eram considerados, na verdade, como recônditos empresários, sobretudo quando se sabia que os mesmos desenvolviam de forma livre e desimpedida as mais diversas empresas econômicas a partir de seu domínio quase que exclusivo da mão de obra nativa e da produtividade de suas 
propriedades $^{9}$.

Destruir, portanto, o inimigo comum, solapando esta República alternativa, era o sintoma de uma nova hegemonia que começava a se afirmar. Para Mendonça Furtado, havia de se reformar as vidas dos índios, responder aos desafios do desenvolvimento da região e de aparelhar um novo sistema que se opusesse rigorosamente ao "letárgico" sistema religioso. Tratava-se de um mundo em crise, incapaz de dar os saltos planejados pela Metrópole para a consecução do desenvolvimento econômico; inviável ainda, no sentido de tomar o caminho do futuro.

Critérios de modernidade, que em diferentes graus eram o fundamento social em que o governador Mendonça Furtado se apoiava, engendravam no contexto colonial amazônico, significações importantes e contraditórias em relação aos problemas da superação do atraso da escravidão dos índios. Mendonça Furtado escreve que a existência de um governo que age com responsabilidade e eficiência, enfrentando os problemas do baixo nível de civilização oferecido pelos missionários, é a primeira condição para que exista um regime moderno. Ele mesmo dizia não haver dúvidas quanto ao fato das religiões serem as que têm "maior interêsse na administração e serviço dos índios, e de que êles se conservem no estado presente ou ainda em maior apêrto para, em consequência, ficar a sua administração mais livre, elas mais poderosas, os índios mais tiranizados e o povo acabado de precipitar" (MENDONÇA, 2005, p. 79).

Desferir golpes deliberados contra a intervenção jesuítica era uma ação empreendida autonomamente por um Estado cuja lógica estava inscrita numa nova ordem racional, na qual o Regimento das Missões equivalia a um movimento antinômico da sociedade escravista:

Parece-me que está é uma excelente ocasião de se dar um grande corte, no Regimento para o Procurador dos índios, na forma das leis de S. Majestade, dando nêle poder ao dito Procurador para averiguar se se criam os índios na forma que os possamos dispor a fazer com êles uma República polida e civil, deixando-se inteiramente o sistema presente, em

\footnotetext{
${ }^{9}$ Em carta a Diogo de Mendonça Côrte-Real, datada de 23 de maio de 1757, o governador do Grão-Pará informa, dentre outros, o comércio das ordens religiosas no Estado. Em relação aos jesuítas, afirma que estes negociam "azeite de andiroba, manteiga de tartarugas, salga de peixe, uma grande parte das carnes, farinhas, feijão, arroz, e finalmente quasi todos os comestiiveis, e um grande numero de arrobas de algodão, bem como assucar e aguardente" (MENDONÇA, 2005).
} 
que são educados como se fôssem irracionais, e desterrando neste Regimento muitos abusos que estão estabelecidos, e muitos dêles pretextados com o Regimento das Missões. (MENDONÇA, 2005, p. 81)

O poder político, econômico e cultural dos padres jesuítas representava o fracasso do Estado monárquico português. A rede de inércias da educação religiosa, a perversidade do atraso dos índios, a crueldade de uma rotina devastadora com que convivia o governo, eram na essência, a face do ceticismo. As mensagens de Mendonça Furtado ao Marquês de Pombal, por vezes deveras apocalípticas, sobre a Companhia de Jesus, anunciam a "miudeza" e a "vulgaridade" das religiões, advertindo sobre a autoridade eclesiástica - cuja analogia ao falso messianismo era inevitável, por prejudicarem incontáveis almas. Argumenta, ainda, que aquela seria "uma boa ocasião de principiar a arruinar o inimigo comum dêste Estado, que é o regimento das Missões, com o qual se tem precipitado estas duas grandes capitanias, que, apesar de terem tantas e tão preciosas drogas, estão reduzidas à última penúria e miséria" (MENDONÇA, 2005, p. 82).

Nessa preciosa região, romper com os velhos hábitos, com os laços de escravidão que se prendem nos vícios e nos procedimentos desastrosos, assumia literalmente um sentido realista de enfrentar o primitivismo dos silvícolas e os privilégios materiais das religiões.

Assim, era urgente que os pombalinos lutassem para que o Estado predominasse como detentor do poder político e econômico. É natural, portanto, que se procurasse revestir de conteúdo religioso as novas significações políticas, ditadas para uma nova realidade no sentido de modernização dos costumes, expurgando o poder temporal dos padres jesuítas.

A crise com os jesuítas estava bastante caracterizada. Derrubar o mito jesuítico de desenvolvimento moral constituído pelos valores evangélicos de uma vida cristã se delineava como o ideal construído pelos pombalinos para introduzir novas estruturas com as dimensões de um novo modelo de vida, agora controlado pela organização do Estado, daí a importância de "reduzir esta gente a pastores espirituais que curem da alma, sem que perturbem tão escandalosamente o sossêgo e comércio público, de que depende a subsistência e aumento do Estado" (MENDONÇA, 2005, p. 147), bem como 
instituir a obrigatoriedade da língua portuguesa e dos casamentos entre índios e imigrantes açorianos ${ }^{10}$.

Mas se, entretanto, desvelarmos o aparente discurso religioso, veremos que a visão do Gabinete de Pombal postulava, de antemão, uma opção pela modernização da escravidão, pois se os padres se interpunham como obstáculos do desenvolvimento político e econômico, os escravos negros, por sua vez, indicavam um novo caminho de mudanças para esta terra fértil: "O que vos posso dizer em poucas palavras é que este Estado é o melhor da América Portuguêsa" (MENDONÇA, 2005, p. 946).

O funcionamento das ideias modernas - idealizado no plano do Diretório - é ligado ao projeto de fundação de vilas, tomado como um movimento de povoação civil e cristã, dentro da perspectiva de se governarem os índios por si mesmos.

Sob o discurso da "civilidade" e da "cristianidade completa", os pombalinos denunciam com veemência a "irresponsabilidade moral" que governava os padres da Companhia, cujo verdadeiro conhecimento da fé era sinônimo de superficialidade na instrução dos índios. A partir destes sentimentos e decorrências, a expulsão não tardaria a chegar.

\footnotetext{
${ }^{10}$ Açores: Arquipélago de ilhas portuguesas no Atlântico.
} 


\section{Referências}

AVELLAR, Hélio de Alcântara. História administrativa do Brasil: a administração pombalina. Vol. 5. $2^{\mathrm{a}}$ ed. Brasília: FUNCEP/ Ed. UNB, 1983.

BAENA, A. L. M. Compêndio das eras da Província do Pará. Belém: Universidade Federal do Pará, 1969.

BETTENDORFF, Pe. J. F. Crônica da missão dos padres da Companhia de Jesus no Estado do Maranhão. 2a . ed. Belém: Fundação Cultural do Pará Tancredo Neves, 1990.

BEOZZO, J. O. Leis e regimentos das Missões: política indigenista no Brasil.

São Paulo: Loyola, 1983.

BERGER, Manfredo. Educação e dependência. 4. ed. São Paulo: DIPEL, 1984.

BOSI, A. Dialética da colonização. 2. ed. São Paulo: Companhia das Letras, 1992.

CAEIRO, J. Sobre o exílio das províncias transmarinas da Assistência portuguesa da Companhia de Jesus durante o Ministério do Marques de Pombal. Bahia: Academia Brasileira de Letras, 1936.

CALMON, Pedro. História da civilização brasileira. Brasília: Senado Federal, Conselho Editorial, 2002.

DAMASCENO, Alberto. Origens da educação estatal na América Portuguesa. Belém: Editora Açaí. 2012.

FERNANDES, Francisco Assis Martins. Comunicação na pedagogia dos jesuítas na era colonial. São Paulo: Loyola, 1980.

GOMES, Joaquim Ferreira. Para a história da educação em Portugal: seis estudos. Porto: Porto Editora, 1995.

HAUBERT, Maxime. Índios e Jesuítas no tempo das missões. São Paulo: Companhia das Letras; Círculo do Livro, 1990.

HOLANDA, S. B. História geral da civilização brasileira: Tomo 1: A época colonial; v. 1-2. 6. ed. São Paulo: DIFEL, 1985.

ILDONE, J. Noções de história da Vigia. Pará: CEJUP, 1991.

LEITE, Pe. S. História da Companhia de Jesus no Brasil. Lisboa: Livraria Portugália; Rio de Janeiro: Instituto Nacional do Livro, 1943.

MAUÉS, H. et al. Ação das ordens e congregações religiosas na Amazônia. Belém: Grêmio Literário Português, 1968. 
MEIHY, J. C. S. B. Ensaio introdutório: "Vieira: o mapa do homem impossível”. In: VIEIRA, Pe. A. Escritos instrumentais sobre os índios. São Paulo: EDUC; Loyola; Giordano, 1992.

MENDONÇA, M. C. A Amazônia na era pombalina: correspondência do Governador e Capitão-General do Estado do Grão-Pará e Maranhão, Francisco Xavier de Mendonça Furtado: 1751-1759. 2. ed. Brasília-: Senado Federal, Conselho Editorial, 2005.

REIS, A. C. F. A Amazônia e a cobiça internacional. São Paulo: Companhia Editora Nacional, 1972.

REIS, A. C. F. História de Óbidos. 2. ed. Rio de Janeiro: Civilização Brasileira, 1979.

RODRIGUES, J. B. A Língua geral do Amazonas e o Guarany: observações sobre o alfabeto indígena. Revista Trimensal do Instituto Histórico e Geographico Brasileiro, Rio de Janeiro, Tomo LI, supl., p. 73-110, out., 1888.

ROSÁRIO, Maria José Aviz do; MELO, Clarice Nascimento de. A educação jesuítica no Brasil colônia. Revista HISTEDBR <periódicos.sbu.unicamp.br/ojs/índex.php/histedbr/issue/view/696>, Campinas, n. 61, p. 379-389, 2015 - ISSN: 1676-2584.

SOUTHEY, R. História do Brasil. Belo Horizonte: Itatiaia; São Paulo: EDUSP, v. 3, 1981.

SWEET, D. G. Francisca: escrava da terra. In: Anais da Biblioteca e Arquivos Públicos do Pará. Tradução de Mônica Macedo Assayag. Tomo XIII. Belém: SECDET, 1983. p. 283-304.

VIEIRA, Pe. A. Escritos instrumentais sobre os índios. São Paulo: EDUC; Loyola; Giordano, 1992.

WEHLING, Arno; WEHLING, Maria José C. M. Formação do Brasil Colonial. Rio de Janeiro: Nova Fronteira, $2^{\circ}$ Ed., 1999. 